\title{
Workers' perception towards statutory labour welfare benefits with special reference to engineering sector
}

\author{
Shreshth Chhabra ${ }^{1, *}$, Sachin Mittal ${ }^{2}$, Vivek S. Kushwah ${ }^{3}$ \\ ${ }^{1,2}$ Member of Faculty, ${ }^{3}$ Director, ${ }^{1}$ Daly College Business School, Indore, ${ }^{2}$ Jaipuria Institute of Management, Indore, ${ }^{3}$ IBMR, IPS \\ Academy, Indore, Madhya Pradesh, India
}

*Corresponding Author:

Email: chhabrasonu@rediffmail.com

\begin{abstract}
In classical economics, labour is one of the three factors of production, along with capital and land. The word welfare has historically been related to happiness and prosperity. Labour welfare implies the adoption of measures to promote the physical, social, psychological and general well-being of the working population. Welfare work in any industry aims, or should aim, at improving the working and living conditions of workers and their families. Adequate levels of earnings, safe and humane conditions of work and access to some minimum social security benefits are the major qualitative dimensions of employment which enhance quality of life of workers and their productivity.

Constitution of India, national and internal labour bodies, labour laws, especially the factories act, 1948 and contract labour (Regulation and abolition) Act, 1970 strive to make the working conditions more humane with a view to make workers not only satisfied but also productive. The paper studies the statutory welfare facilities and the provision of leaves as enumerated under Factories Act and contract labour act and social security provisions under different acts. The study was conducted in engineering companies to know the perception of workers about the different dimensions of welfare i.e. statutory welfare measures, social security measures and leaves provided and also to know the impact of worker's status (permanent/contractual) on such measures. The sample comprised of 97 workers employed with different engineering companies. These companies can be categorised as light and heavy engineering companies employing varying strength of workers. The results indicated that though significant workers were satisfied with the welfare facilities, some workers perceive welfare facilities to be inadequate and there is impact of worker's status on the perception of workers.
\end{abstract}

Keywords: Labour, Welfare, Engineering, Permanent worker, Contractual worker.

\section{Introduction}

In classical economics, labour is one of the three factors of production, along with capital and land. Labour can also be used to describe work performed, including any valuable service rendered by a human agent in the production of wealth, other than accumulating and providing capital. Labour is performed for the sake of its product or, in modern economic life, for the sake of a share of the aggregate product of the community's industry (Merriam Webster, 2014).

Section 2(1) of Factories Act defines Worker as a person employed, directly or through any agency, whether for wages or not in any manufacturing process or in cleaning any part of the machinery or premises used for a manufacturing process in any other kind of work incidental to, or connected with the manufacturing process, or the subject of the manufacturing process. (Mallick, 2009) The amendment by Act 94 of 1976 furthers that if a work in the factory has been given on contract to be executed by the contractor and the contractor in execution of the work employs workmen, such workmen would be workers within the definition of worker under the act (Srivastava, 2000). Besides this, Contract labour Regulation and abolition Act, 1970, defines Workman as any person employed in or in connection with the work of any establishment to do any skilled, semi-skilled or unskilled, manual, supervisory, technical or clerical work for hire or reward, whether the terms of the employment be expressed or implied but does not include a person in managerial or administrative capacity or out - worker (Saraf, 2010). To add, a workman shall be deemed to be employed as "contract labour" in or in connection with the work of an establishment when he is hired in or in connection with such work by or through a contractor, with or without the knowledge of principal employer (Mallick, 2009). The word welfare has historically been related to happiness and prosperity. Chambers' Twentieth Century Dictionary defines welfare as "state of faring or doing well: freedom from any calamity, enjoyment of health, prosperity (Fine Dictionary, 2013).

Labour welfare can be defined as, "Anything done for the comfort and improvement, intellectual and social, of the employees over and above the wages paid, which is not a necessity of the industry (Punekar, Deodhar, and Sankaran, 2004). N.M. Joshi observed that labour welfare "covers all the efforts which employers make for the benefit of their employees over and above the minimum standards of working conditions laid down by the Factories Act and the provisions of the social legislations providing against accident, old age, unemployment and sickness" (Gupta, 2007). 
Hence, labour welfare implies the adoption of measures to promote the physical, social, psychological and general well-being of the working population. Welfare work in any industry aims, or should aim, at improving the working and living conditions of workers and their families. Adequate levels of earnings, safe and humane conditions of work and access to some minimum social security benefits are the major qualitative dimensions of employment which enhance quality of life of workers and their productivity.

The present study focused on labour welfare in engineering sector. Indian engineering has got a strategic importance to economy because of its high integration with other industrial sector (CCI, 2015). The engineering sector in India interest foreign participants as it has comparative advantage in terms of manufacturing costs, technology and innovation (IBEF, 2015). According to Dun \& Bradstreet India, the Engineering sector is the largest in the overall industrial sectors in India, with the presence of both large and small players and can be catagorised into heavy \& light engineering. Light engineering industry is one of the largest segments and is highly labour intensive (Business Knowledge Resource, Nd). Thus the sector is characterized by being labour intensive; hardly employs females, increasing presence of contractual labours and presence of large and small players.

\section{Review of Literature}

Ogura and Okada (2002), asserts that inorder to achieve work - family balance and to address issues like house work and child care, the daily work hours, commuting time or the number of days off per week were important consideration. This was also necessary purposes such as recovering from accumulated fatigue, refreshing mind and body, and spending time with family members. In addition, for such purposes as taking care of children, sick relatives, or elderly relatives, and retraining to improve the occupational skills of workers themselves, a certain amount of longterm holidays or leave were necessary. Ghai (2003), in his study, stressed on the need of Information regarding remuneration and working conditions, social security arrangements, and the nature and mechanisms for negotiation, representation and worker participation. A good deal of this information is of necessity of a qualitative nature, assessing the effectiveness of laws, institutions and procedures and practices in the various domains pertaining to decent work (The concept of "decent work" was launched in these terms in 1999, in the Report of the Director-General to the International Labour Conference meeting in its 87th Session and comprises of employment, social protection, workers' rights and social dialogue).

Mini (2010), in her research on social security of labour in the new Indian economy was of the view that in India, the laws governing social security laws are quite old and minor amendments on coverage or on contribution amount are made. The law structure has several drawbacks like multiplicity of laws, shortage of coverage, lack of policy, scarcity of implementation mechanism and above all, lack of clarity of principles which need to be followed. In organized sector, there are many workers who work on daily wages or on contract for short period and are virtually out of the "protection net". To add to the dismal, the names of these workers may not be on the rolls and there may be no evidence in the office about their whereabouts as they come, work, get wages and go. According to the researcher, in order to effectively implement social security system corporations should be made more accountable towards ensuring social security of its workers. The social security net should be available to all workers without any discrimination. There should be compulsory methods for all to invest in such plans that neither the government nor the corporation is burdened at the time of worker's misery. Rather than aggregating the existing programmes of social security, all the existing systems under various enactments should be streamlined to avoid multiplicity and coverage extended to all workers in a user friendly manner. Under such system workers will become more confident and efficient.

Gupta (2013) in his review labour welfare and social security in globalizing economy stresses that welfare of labor is an important aspect today which we cannot ignore if we want progress of our industry. It is essential to make safety and other welfare arrangements for labour. Freedom from want and security against economic fear is the minimum that has to be secured to its people in the country. The quest for social security and freedom from want and distress has been the consistent urge of man through the ages. The Government and the factory owners must fully understand the labor psychology and a change in their outlook and attitude is desired to secure the industrial peace. Nothing should be done under threat but on a clear understanding that whatever is good and is due to the labor, must be given. Industry owners should treat the workers as co-partners. Similarly, workers' duty is to improve the work efficiency and help in securing better production resulting in greater profits and prosperity of the industry. Then alone a socialist democracy is possible in this country and industrial relations of a higher order can be maintained for the benefit of the country and the community.

Bhati \& Kumar (2013), carried out study on provision of welfare under Factories Act \& Its impact on employee satisfaction in five engineering companies from Gujarat drawing a sample of 250 employees. The research focused on employee satisfaction towards welfare facilities under Factories Act 1948. The impact of welfare provisions on employee satisfaction was studied by the way of correlation technique and it also measures the difference in terms of employee satisfaction towards welfare provision through one way 
Annova test. It was found that washing facility, facility for storing \& drying clothes, sitting arrangement, firstaid facility, canteen, shelters, lunchroom, rest room and welfare officer are correlated with employee satisfaction. None of the organization from which the sample was drawn gets affected by crèche facility because as a part of the act, this provision is to be made only if 30 or more female workers are employed. The researchers suggested that the provisions provided to the employees in each industry should always be made more beneficiaries for their welfare. So, for this each industry should appoint the welfare officer who can take better care for the welfare facility of the employees in an industry. The study found that the employees have positive attitude towards their industry for the welfare provisions. The reason behind this result is that these are the factors that lead to satisfaction \& if they are not present can sometimes lead to dissatisfaction.

The present study focused on the perception of workers and especially permanent and contractual workers regarding the different dimensions of welfare i.e. statutory welfare, social security measures, weekly and annual leave facilities provided. Since its a perceptual study, it looked more into the adequacy of the facilities extended. It would help employers to identify the gaps in the present system and also suggest measures to improve the same. This study was carried out in Pithampur industrial estate of Madhya Pradesh. Based on the literature review and to the best of the knowledge of the researchers, studies done so far have focused on different parts of India. Till date no study has focused on this part of state. Hence probably this is the first formal attempt to study the perception of workers regarding welfare measures in the Pithampur industrial estate.

\section{Objectives of the study}

1. Study the perception of workers towards the welfare facilities provided in engineering sector companies located in Pithampur.

2. Compare the perception of permanent workers and contractual workers towards the welfare facilities provided in engineering sector companies located in Pithampur.

\section{Research Methodology}

The study: The present study is descriptive in nature which is a part of formal research design.

Sampling Plan: 97 workers employed in engineering companies of varying employee strength spread across Pithampur industrial estate (M.P.). 400 questions were distributed off which 144 questionnaires were received back. Out of the filled questionnaire biased, half filled or inappropriate questionnaires were rejected leaving it to 97.

Sampling characteristics: The sample comprised of 53 $(54.6 \%)$ permanent and $44(45.4 \%)$ contractual workers. (Appendix, Table 1.1). Some contractual workers were diffident towards the study and the best known reason was the apprehension that either they would lose the job if company comes to know of their participation or their perception that researchers were disguised representatives of the company. Though the researcher tried to assure them that their identity would not be disclosed and data would be used strictly for academic purpose only, still they would come up with one - another reason for not participating. Some contractual workers took the questionnaires but never returned due to their shift in working place (in some cases outside the state).

Table 1.1: Sector * Worker Status Cross-tabulation

\begin{tabular}{|l|l|l|c|c|c|}
\hline & & & \multicolumn{2}{|c|}{ Worker status } & \multirow{2}{*}{ Total } \\
\hline & & & Permanent & Contractual & \\
\hline \multirow{2}{*}{ Sector } & Engineering & Count & 53 & 44 & 97 \\
\cline { 3 - 5 } & & $\%$ within Sector & $54.6 \%$ & $45.4 \%$ & $100.0 \%$ \\
\hline
\end{tabular}

Tools for data collection: Primary data was collected through self - administered questionnaire and the respondents will fully chose the answer. Our self as researchers were in person present at the Industrial estate. We seeked official permission to carry on the survey - to which most of the organizations refused, and least accepted. Hence in most of the cases labours were approached individually and/or through trade unions which supported the research work and helped in data collection.

It was observed that workers with one year plus experience had adequate knowledge of laws (may not be technical per se). They gain this knowledge through exposure at work, colleagues, trade unions and general environment in which they live (Pithampur being an industrial estate has significant population of workers residing locally and in nearby areas).

The questionnaire was constructed primarily according to welfare measures described in the Factories act, 1948; Contract labour (Regulation and abolition) Act, 1970, Social security acts like Employees' State Insurance Act, 1948, Maternity Benefit Act, 1961, Workmen Compensation Act, 1923, Employee Provident Fund Act, 1952, Payment of gratuity, 1972 and labour welfare inventory by Dr. S K Srivastava (2002). The questions of similar nature were grouped together and welfare facilities were categorized into six facilities, namely washing, shelter or rest room, medical, canteen, labour welfare officer and crèche, followed by social security measures and leaves (weekly and annual). The statements in the 
questionnaire aimed at looking the adequacy of the facility. The questionnaire was in Hindi language as it is the official language of Madhya Pradesh and is the most widely spoken and easily understood too (Government of Madhya Pradesh, 2013). Secondary data comprised of publications from ILO, labour department, Government of India, national and international journals, books, Phd thesis and other relevant resources.

Tools for Data Analysis: To derive a meaningful outcome, the tools used were frequency distribution, mean value and t-test. These tools were applied through SPSS. All the tools used were meant to answer specific questions to fulfill certain objectives of this study.

\section{Results and Discussion}

Data was collected from 97 workers and the analysis is presented below on the basis of these broad categories and subcategories.

Perception of workers towards the welfare facilities provided by engineering sector companies located in Pithampur: Most of the workers agreed or strongly agreed that shelter facilities, medical facilities and canteen facilities, were adequate. However for facilities like washing, crèche and labour welfare officer carrying welfare programmes have close differences between agreement and disagreement of being adequate. On the social security front, most of the workers agreed or strongly agreed for provident fund and employee state insurance benefits and weekly off. However there appeared to be some reservations on other social security measures and annual paid leaves. (Table 1.2)

Table 1.2:

\begin{tabular}{|c|c|c|c|c|c|}
\hline Facility $\backslash$ Response & $\begin{array}{l}\text { Strongly } \\
\text { Disagree }\end{array}$ & Disagree & Neutral & Agree & $\begin{array}{c}\text { Strongly } \\
\text { Agree }\end{array}$ \\
\hline \multicolumn{6}{|l|}{$\begin{array}{l}\text { Washing Facility (Statutory welfare } \\
\text { facilities) }\end{array}$} \\
\hline Facility for washing & 27 & 22 & 5 & 22 & 21 \\
\hline $\begin{array}{l}\text { Separate washing facility for male and } \\
\text { female workers }\end{array}$ & 41 & 26 & 6 & 12 & 12 \\
\hline Availability of water & 28 & 18 & 1 & 18 & 32 \\
\hline Place for keeping and drying clothes & 2 & 8 & 1 & 52 & 34 \\
\hline Mean Value & 24.5 & 18.5 & 3.3 & 26.0 & 24.8 \\
\hline \multicolumn{6}{|l|}{ Shelter/Rest room } \\
\hline Availability of Shelter or rest rooms & 1 & 1 & 0 & 48 & 47 \\
\hline Quality of Shelter or rest rooms & 1 & 1 & 0 & 46 & 49 \\
\hline Sitting Arrangement & 1 & 9 & 0 & 45 & 42 \\
\hline Mean Value & 1.0 & 3.7 & 0.0 & 46.3 & 46.0 \\
\hline \multicolumn{6}{|l|}{ Medical Facility } \\
\hline First - Aid Facility & 0 & 1 & 0 & 17 & 79 \\
\hline Sick room & 1 & 2 & 0 & 31 & 63 \\
\hline Medical officer & 1 & 2 & 3 & 19 & 72 \\
\hline Worker is taken to hospital & 0 & 0 & 0 & 12 & 85 \\
\hline Mean Value & 0.5 & 1.3 & 0.8 & 19.8 & 74.8 \\
\hline \multicolumn{6}{|l|}{ Canteen Facility } \\
\hline $\begin{array}{l}\text { Food I snacks available at } \\
\text { concessional rate }\end{array}$ & 8 & 20 & 0 & 39 & 30 \\
\hline Sitting arrangement in canteen & 2 & 6 & 0 & 52 & 37 \\
\hline Drinking water & 0 & 0 & 0 & 13 & 84 \\
\hline Mean Value & 3.3 & 8.7 & 0.0 & 34.7 & 50.3 \\
\hline \multicolumn{6}{|l|}{ Labour Welfare Officer } \\
\hline $\begin{array}{l}\text { Labour welfare officer carries welfare } \\
\text { programmes }\end{array}$ & 27 & 13 & 0 & 39 & 18 \\
\hline \multicolumn{6}{|l|}{ Crèche Facility } \\
\hline Crèche & 77 & 17 & 2 & 0 & 1 \\
\hline Availability of Aya & 73 & 22 & 2 & 0 & 0 \\
\hline Mean Value & 75.0 & 19.5 & 2.0 & 0.0 & 0.5 \\
\hline \multicolumn{6}{|l|}{ Social Security Measures } \\
\hline Eligible workers get PF benefits & 2 & 2 & 0 & 24 & 69 \\
\hline
\end{tabular}




\begin{tabular}{|c|c|c|c|c|c|}
\hline Gratuity benefits & 15 & 24 & 8 & 15 & 35 \\
\hline Disability benefits & 19 & 43 & 7 & 17 & 11 \\
\hline Insurance scheme for workers & 25 & 49 & 0 & 18 & 5 \\
\hline ESI benefits & 0 & 1 & 1 & 19 & 76 \\
\hline $\begin{array}{llll}\begin{array}{l}\text { Eligible } \\
\text { benefits }\end{array} & \text { workers get maternity } \\
\end{array}$ & 59 & 25 & 5 & 6 & 2 \\
\hline Mean Value & 20.0 & 24.0 & 3.5 & 16.5 & 33.0 \\
\hline Weekly off (Leaves) & 0 & 1 & 1 & 30 & 65 \\
\hline $\begin{array}{l}\text { Sufficient leaves with wages on } \\
\text { annual basis }\end{array}$ & 14 & 32 & 0 & 18 & 33 \\
\hline Mean Value & 7 & 16.5 & 0.5 & 24 & 49 \\
\hline
\end{tabular}

It can be analysed from Table 1.2 that most of the workers opined that the facilities extended to them were adequate. However the rest workers were either in disagreement or neutral (though 'neutral' percentage being very low) regarding the benefits provided been adequate. The disagreement may be attributable to these reasons - one, difference existent between permanent and contractual labour. Manufacturing companies have mostly been unfair to contract workers, who earn much less than permanent workers and enjoy fewer benefits (Das, 2014). Jindal (2014) was of opinion that there has been a significant increase in number of contractual labour and this increase is socially harmful as it is deteriorating the economic security of the labour force. They are also being denied benefits which are being allowed by corporate to their permanent workers. On similar lines Sen (2010) echoed, in many cases employers also didn't wish to extend the same facilities (as to permanent workers) to the contractual ones owing to their skill and education level.

Second reason was the varying worker strength across the companies. Welfare facilities as depicted in Factories Act, 1948 are incremental in nature i.e. more of them were applicable with increase in worker strength. Some facilities like crèche which is gender based is least seen and so is true with maternity benefits because engineering was classified as 'hard' work. Females were minimally employed in such 'hard' work category. Annual paid leaves were generally available to permanent workers. Similar examples could be drawn from research in a much developed economy- United States. Ray, Sanes and Schmitt (2013), quoted a government survey data stated that only $35 \%$ part timers were likely to have paid vacations (35 percent) as compared to $91 \%$ full -timers. This problem of low wage and part time workers is more with small establishments, as compared to those employed with medium and large organisations. Even if low - wage, part time, and small business employees receive paid vacations, they typically receive far fewer paid days off than higher wage, full time, employees in larger establishments.

However, companies should take care of these facilities beyond the averages and distribution. As per Herzberg's two factor theory, welfare can be categorized as a hygiene factor. Hygiene factor were the bare minimum to maintain satisfaction. The absence of hygiene factor in a job, would lead to dissatisfaction. Therefore company should first bequeath hygiene factors and then only other motivators would work effectively (Herzberg, 1959, cited in Ramprasad, 2013).

Comparison of perception between permanent workers and contractual workers towards the welfare facilities provided by engineering sector companies located in Pithampur: It can be inferred from table no. 1.4 that the $\mathrm{F}$ value of 6.146 for permanent and contractual workers is significant at $5 \%$ level. It implies that the mean perceptions score of permanent workers and contractual workers differ significantly from each other. Hence the null hypothesis $\left(\mathrm{H}_{0}\right)$ "There is no significant difference between the perception of permanent workers and contractual workers towards the welfare facilities provided in engineering sector companies located in Pithampur" is rejected. Further, the mean perceptions score of permanent workers (3.99) is significantly higher than the mean perceptions score of contractual workers (3.15) (Table 1.3). This indicated that there existed difference between the perception of permanent and contractual workers towards the adequacy of welfare facilities. Therefore it may also be concluded that contractual workers were not getting proper welfare facilities as compared to permanent workers in engineering sector in Pithampur of Madhya Pradesh.

Table 1.3: T-Test

\begin{tabular}{|l|c|c|c|c|}
\hline \multicolumn{1}{|c|}{ Worker status } & N & Mean & Std. Deviation & Std. Error Mean \\
\hline Permanent & 53 & 3.9943 & .37643 & .05171 \\
\hline Contractual & 44 & 3.1591 & .25819 & .03892 \\
\hline
\end{tabular}

Most of the studies also supported the existence of such differences. Contractual workers are seldom granted such facilities either because of law (in case of gratuity) or employer/contractor saving cost (Dhoot, 2012). In some 
cases the name of many contractual labours does not even appear on the muster rolls of the company. Hence company employs more workers than it actually shows. This is equally evident in Manesar plan (Sen and Anand, 2011). R C Jain, former group vice-chairman, Eicher agreed that "temporary workforce is needed to meet the peaks of 20-30 percent growth rates. But that does not mean company should treat the contract labour unfairly in terms of compensation, working conditions or what have you in terms of facilities for a permanent worker. In my mind, the flexibility premium which organizations enjoy should be paid out in compensation to temporary workforce. Obviously quite a few companies are not doing this today. If companies believe they can cut costs in this manner, I don't think that is a fair thing to do. Managements have to learn how to handle the contract labour" (Mishra, 2012). This calls for minimizing the differences between permanent and contractual workers in all logical, legal and likely ways.

Table 1.4: Independent Samples Test

\begin{tabular}{|l|c|c|c|c|c|c|c|}
\hline & \multicolumn{7}{|c|}{ Levene's Test for Equality of Variances } \\
\hline & $\mathbf{F}$ & Sig. & $\mathbf{t}$ & $\mathbf{d f}$ & $\begin{array}{c}\text { Sig. } \\
\text { (2-tailed) }\end{array}$ & $\begin{array}{c}\text { Mean } \\
\text { Difference }\end{array}$ & $\begin{array}{c}\text { Std. Error } \\
\text { Difference }\end{array}$ \\
\hline $\begin{array}{l}\text { Equal variances } \\
\text { assumed }\end{array}$ & 6.146 & .015 & 12.477 & 95 & .000 & .83525 & .06694 \\
\hline $\begin{array}{l}\text { Equal variances } \\
\text { not assumed }\end{array}$ & & & 12.906 & 91.932 & .000 & .83525 & .06472 \\
\hline
\end{tabular}

\section{Conclusion}

It can be concluded from the above analysis that most of the workers perceive the facilities to be adequate and on the other hand some workers have a perceptual disagreement on the adequacy of such facilities. Companies should look not only into the compliance with act but should equally look in how the facilities are perceived by the workers. Providing facilities would call for investment, which would pay off only when it add to the comfort level of workers and actually bring in welfare. When companies intend to abide by law, they should do it in the manner that workers' perceive it to be beneficial.

The study also found distinction between permanent and contractual regarding the welfare facilities. Companies look for flexibility in workforce through employment of contractual workers and this employment pattern would stay too. The study does not suggest that contractual workers should not be used or there existed wide differences in treatment towards such workers. Since welfare facilities in factories act are more or less similar to contractual worker act, therefore it is suggested that companies should not distinguish between workers in all possible ways. Distinctions could always be there in logical aspects like providing uniform only to permanent workers. The perceptual gaps that exist between these classes of workers could lead to labour unrest and hence calls for corrective measures either in terms of measures adopted or a mental revolution in F.W. Taylor's term. Management, permanent and contractual workers are the wheels of the same production cycle and together this cycle will move in the direction of prosperity when it is properly oiled in terms of profitability and welfare and least of friction will lead towards good industrial relations.

\section{References}

1. Bhati P P and Kumar M A (2013). Provision of Welfare under Factories Act \& Its Impact on Employee

Satisfaction. Journal of Business Management \& Social Sciences Research. 2 (2)

2. Business Knowledge Resource (Nd). Light Engineering Industry. Retrieved from http://business.gov.in/Industry_services/light_industry.ph p. accessed on 21/12/2013.

3. Corporate Catalyst (India) Pvt. Ltd. (CCI) (2015). A brief report on engineering sector of India. retrieved from http://www.cci.in/pdfs/surveys-reports/EngineeringSector-in-India.pdf. accessed on 12/12/2015

4. Das G (2014). The manufacturing sector continues to struggle with labour strife. It is time for some soul searching. Business Today, June 22, retrieved from http://www.businesstoday.in/magazine/coverstory/manufacturing-sector-struggle-with-labourstrife/story/206793.html. accessed on 15/09/2015.

5. Dhoot V (2012). Administration of existing labour laws is very poor: Arun Maira. Planning Commission, available from, http://articles.economictimes.indiatimes.com/201212-13/news/35796954_1_labour-laws-arun-maira-humanresources, accessed on 31/05/2013.

6. Fine dictionary (2013). Welfare Definitions. Retrieved from http://www.finedictionary.com/welfare.html.accessed on 10/06/2013.

7. Ghai D (2003), Decent Work: Concept and Indicators, International Labour Review, 142(2).

8. Government of Madhya Pradesh (2013), State Profile, available from http://www.mp.gov.in/web/guest/stateprofile, accessed on 7/09/2016.

9. Gupta A (2013), Labour welfare and social security in globalizing economy, Global Advanced Research Journal of Economics, Accounting and Finance, 2(3) pp - 062066,retrieved from http://garj.org/garjeaf/index.htm, accessed on 16/07/2013.

10. Gupta M (2007). Labour Welfare and Social Security in Unorganised Sector. New Delhi: Deep \& Deep Publications.

11. IBEF (2015), Engineering Industry in India. retrieved from http://www.ibef.org/industry/engineeringindia.aspx, accessed on 10/09/2015. 
12. Jindal J (2014) Time to Manage Contract Labour Unrest in India, International Journal of Emerging Research in Management \&Technology, 3 (4).

13. Mallick M R (2009). Labour \& Industrial Law manual. New Delhi: Professional book publishers. pp - 343-345.

14. Merriam Webster (2014). Labour. Retrieved from http://www.merriamwebster.com/dictionary/labour.accessed on 05/01/2014.

15. Mini S (2010). Social security of labour in the new Indian economy. Phd Thesis submitted to Cochin University of science \& technology. retrieved from http://dyuthi.cusat.ac.in/xmlui/bitstream/handle/purl/2788 /Dyuthi-T0809.pdf? sequence=1. accessed on 03/08/2013.

16. Mishra A K (2012), R. C. Jain: Can't Treat Contract Labour Unfairly. retrieved from http://www.forbesindia.com/article/close-range/r-c-jaincant-treat-contract-labour-unfairly/33454/1. accessed on 21/08/2014.

17. Ogura K and Okada Y (2002), Research on Annual Paid Holidays, Research Report No.152, retrieved from www.jil.go.jp/english/reports/documents/jilresearch/no152.pdf, accessed on 25/06/2010.

18. Punekar S D, Deodhar S B and Sankaran S (2004). Labour welfare, trade unionism and industrial relations. Mumbai: Himalaya Publishing House.

19. Saraf (2010). The contractual labour regulation \& abolition act, 1970 with central \& M.P. Rules. Indore: India Publishing Company.

20. Sen A (2010, November, 25) Employers refuse to put contract workers on par with regular staff. retrieved from http://articles.economictimes.indiatimes.com/2010-1125/news/27609392_1_contract-workers-regular-workerscontract-labour-act. accessed on 20/10/2011

21. Sen S and Anand J (2001). Double Standards. retrieved from http://businesstoday.intoday.in/story/strike-at-autofactories-over-salaries/1/16842.html, accessed on 16/08/2013.

22. Srivastava K D (2000). Commentaries on Factories Act, 1948. Lucknow: Eastern book company. pp - 168.

23. Srivastava S K (2002). Labour Welfare Inventory. Varanasi: Manovaigynaik Parickchan Sansthan. 